\title{
Injection treatment for chronic midportion Achilles tendinopathy: do we need that many alternatives?
}

\author{
M. N. van Sterkenburg • C. N. van Dijk
}

Published online: 3 February 2011

(c) The Author(s) 2011. This article is published with open access at Springerlink.com

An abundant amount of different treatment modalities has been developed for treatment of chronic midportion Achilles tendinopathy. Amongst them are injection treatments with as corticosteroids, Polidocanol, autologous blood, platelet-rich plasma, high-volume injections, hyperosmolar dextrose, brisement, aprotinin and low-dose heparin. The rationale behind these treatments is not always clear. The goal of treatment in general is to relieve symptoms. The main symptom is pain. Up to date, the cause of pain in chronic midportion Achilles tendinopathy has not been elucidated however. So what is the rationale behind these treatments?

Corticosteroid injection has become obsolete in the treatment of midportion Achilles tendinopathy, as tendon rupture has been reported in various cases $[1,2]$. The role of chemical inflammation in this pathology is also a matter of debate, and therefore there is no rationale for antiinflammatory treatment $[3,4]$. Ultrasound-guided treatment with Polidocanol (Ethoxysclerol) was first described in 2002 [5] as an effective and promising method to obliterate neovessels in and around the tendon, which were hypothesized to be a possible cause of pain. Studies on patellar tendinopathy, lateral epicondylitis, supraspinatus tendinitis, and the effectiveness of larger doses in Achilles tendons followed [6-9]. However, not all authors have been able to

M. N. van Sterkenburg ( $\square)$

Department of Orthopaedic Surgery, Academic Medical Center,

University of Amsterdam, 1100, DE, Amsterdam,

The Netherlands

e-mail: m.n.vansterkenburg@amc.uva.nl

C. N. van Dijk

Department of Orthopaedic Surgery, Academic Medical Center,

University of Amsterdam, 1100, DE, Amsterdam,

The Netherlands reproduce a good outcome [10]. The blood vessels are unlikely to be the cause of pain. So what is the rationale behind this treatment?

Platelet-rich plasma (PRP) is possibly the current most controversial in the line-up of minimally invasive treatment options. PRP is defined as 'any elevated level of platelets'. A PubMed search with 'platelet-rich plasma' generates 5,565 results. A search term such as 'autologous blood' or typographic changes would add many more references. Medical companies legitimately take business advantage of this hype. It is currently used in tendon, muscle and ligament repair, osteoarthritis, surgical wounds and chronic ulcers. However, application has been confusing as each method leads to a different product with different biological characteristics and possible applications. There are at least four different products: pure PRP, leucocyte- and PRP, pure platelet-rich fibrin, and leucocyte- and platelet-rich fibrin. Some of these products can be activated or non-activated [11]. Many types of platelet collectors have been developed, and platelet concentration varies from 1.6-4.4 fold between suppliers compared to whole blood [12]. One of the goals seems to be to develop a technique that collects the highest concentration of platelets. Autologous whole blood and PRP have been used in midportion Achilles tendinopathy with the aim of providing growth factors to promote healing in areas of degeneration. However if effective, the questions arise: what concentration would suffice, how long do platelets stay where injected and what is their half-life? Supporting the hypothesis that tendinopathy develops due to a failed chemical healing response would then inducing a new chemical reaction suffice? Or are we trying to induce a chemical response in a neurogenic area? Moreover, in case of chronic midportion Achilles tendinopathy, the exact location of injection is not always clearly described. Is it possible to inject a substance inside the opaque but 
degenerative tendon proper? And if so, is this degenerative area really the cause of complaints? Several studies have reported intratendinous changes in up to $34 \%$ of cadaver specimens, ultrasound and MRI images of patients without complaints [13-18]. A long-term follow-up study published by Alfredson and co-workers revealed persistent structural abnormalities and thickening of the tendon 13 years after intratendinous surgery for Achilles tendinopathy, whereas all patients were satisfied with the results and went back to Achilles tendon loading activities without restrictions [13]. If the pain does not come from the tendon proper, where does it originate? Recently various studies have shown ingrowth of sensory- and sympathetic nerves accompanying neovessels from the paratenon with release of nociceptive substances. Denervating the Achilles tendon by release of the peritendineum would hereby hypothetically suffice to relieve pain. Since pain is the predominant symptom in these patients, and it has never been demonstrated that patients with tendinopathy are more prone to rupture, this approach should be sufficient for obtaining a good clinical outcome.

A minimally invasive technique such as high-volume injection has been successfully performed to produce local mechanical effects in order to release the adhesions formed between peritendineum and tendon proper, thereby obliterating neovascularisation and accompanying neonerves. Brisement, first described in 1997 [19], was initially meant to interrupt the degenerative cycle of the tendon proper by initiating a healing cascade, but in essence seems equivalent to current high-volume injections. Now, could not a combination of these two theories, old and new, be the result of all injections? Meaning that no matter what we introduce, an inflammatory response will be generated? This can be illustrated by a randomized study by De Vos et al., where injection of PRP was compared with saline, producing an equivalent outcome [20]. Corticosteroid injections for lateral epicondylitis did not provide any longterm benefit compared with placebo [21]. Brown et al. performed a double-blind placebo-controlled trial in patients with Achilles tendinopathy, where aprotinin was compared with placebo, showing no statistically significant benefit [22].

Until now, an evidence based algorithm for the (conservative) management of midportion Achilles tendinopathy is unknown. Research on Achilles tendon-related problems is ongoing. Further research should focus on the cause of pain in patients with chronic midportion Achilles tendinopathy. Recognising the cause of pain will help to further define therapeutic strategies.

Open Access This article is distributed under the terms of the Creative Commons Attribution Noncommercial License which permits any noncommercial use, distribution, and reproduction in any medium, provided the original author(s) and source are credited.

\section{References}

1. Shrier I, Matheson GO, Kohl HW III (1996) Achilles tendonitis: are corticosteroid injections useful or harmful? Clin J Sport Med 6:245-250

2. Speed CA (2001) Fortnightly review: corticosteroid injections in tendon lesions. BMJ 323:382-386

3. Alfredson H, Forsgren S, Thorsen K, Fahlstrom M, Johansson H, Lorentzon R (2001) Glutamate NMDAR1 receptors localised to nerves in human Achilles tendons. Implications for treatment? Knee Surg Sports Traumatol Arthrosc 9:123-126

4. Andersson G, Danielson P, Alfredson H, Forsgren S (2007) Nerve-related characteristics of ventral paratendinous tissue in chronic Achilles tendinosis. Knee Surg Sports Traumatol Arthrosc 15:1272-1279

5. Ohberg L, Alfredson H (2002) Ultrasound guided sclerosis of neovessels in painful chronic Achilles tendinosis: pilot study of a new treatment. Br J Sports Med 36:173-175

6. Alfredson H, Harstad H, Haugen S, Ohberg L (2006) Sclerosing polidocanol injections to treat chronic painful shoulder impingement syndrome-results of a two-centre collaborative pilot study. Knee Surg Sports Traumatol Arthrosc 14:1321-1326

7. Alfredson H, Ohberg L (2005) Sclerosing injections to areas of neo-vascularisation reduce pain in chronic Achilles tendinopathy: a double-blind randomised controlled trial. Knee Surg Sports Traumatol Arthrosc 13:338-344

8. Willberg L, Sunding K, Ohberg L, Forssblad M, Fahlstrom M, Alfredson H (2008) Sclerosing injections to treat midportion Achilles tendinosis: a randomised controlled study evaluating two different concentrations of Polidocanol. Knee Surg Sports Traumatol Arthrosc 16:859-864

9. Zeisig E, Ohberg L, Alfredson H (2006) Sclerosing polidocanol injections in chronic painful tennis elbow-promising results in a pilot study. Knee Surg Sports Traumatol Arthrosc 14:1218-1224

10. van Sterkenburg MN, de Jonge MC, Sierevelt IN, van Dijk CN (2010) Less promising results with sclerosing ethoxysclerol injections for midportion achilles tendinopathy: a retrospective study. Am J Sports Med 38:2226-2232

11. Anitua E, Sanchez M, Orive G, Andia I (2009) Shedding light in the controversial terminology for platelet rich products. J Biomed Mater Res A 90:1262-1263

12. Mazzucco L, Balbo V, Cattana E, Guaschino R, Borzini P (2009) Not every PRP-gel is born equal. Evaluation of growth factor availability for tissues through four PRP-gel preparations: Fibrinet, RegenPRP-Kit, Plateltex and one manual procedure. Vox Sang 97:110-118

13. Alfredson H, Zeisig E, Fahlstrom M (2009) No normalisation of the tendon structure and thickness after intratendinous surgery for chronic painful midportion Achilles tendinosis. Br J Sports Med 43:948-949

14. Emerson C, Morrissey D, Perry M, Jalan R (2010) Ultrasonographically detected changes in Achilles tendons and self reported symptoms in elite gymnasts compared with controls-An observational study. Man Ther 15:37-42

15. Haims AH, Schweitzer ME, Patel RS, Hecht P, Wapner KL (2000) MR imaging of the Achilles tendon: overlap of findings in symptomatic and asymptomatic individuals. Skeletal Radiol 29:640-645

16. Kannus P, Jozsa L (1991) Histopathological changes preceding spontaneous rupture of a tendon. A controlled study of 891 patients. J Bone Joint Surg Am 73:1507-1525

17. Khan KM, Forster BB, Robinson J, Cheong Y, Louis L, Maclean L, Taunton JE (2003) Are ultrasound and magnetic resonance imaging of value in assessment of Achilles tendon disorders? A two year prospective study. Br J Sports Med 37:149-153 
18. van Schie HT, de Vos RJ, de JS, Bakker EM, Heijboer MP, Verhaar JA, Tol JL, Weinans H (2010) Ultrasonographic tissue characterisation of human Achilles tendons: quantification of tendon structure through a novel non-invasive approach. Br J Sports Med 44:1153-1159

19. Johnston E, Scranton P Jr, Pfeffer GB (1997) Chronic disorders of the Achilles tendon: results of conservative and surgical treatments. Foot Ankle Int 18:570-574

20. de Vos RJ, Weir A, van Schie HT, Bierma-Zeinstra SM, Verhaar JA, Weinans H, Tol JL (2010) Platelet-rich plasma injection for chronic Achilles tendinopathy: a randomized controlled trial. JAMA 303:144-149

21. Smidt N, van der Windt DA, Assendelft WJ, Deville WL, Korthals-de Bos IB, Bouter LM (2002) Corticosteroid injections, physiotherapy, or a wait-and-see policy for lateral epicondylitis: a randomised controlled trial. Lancet 359:657-662

22. Brown R, Orchard J, Kinchington M, Hooper A, Nalder G (2006) Aprotinin in the management of Achilles tendinopathy: a randomised controlled trial. Br J Sports Med 40:275-279 